\title{
Impact of habitat fragmentation on genetic population structure of roach, Rutilus rutilus, in a riparian ecosystem
}

\author{
Bernd Hänfling ${ }^{1,2, *}$, W. Durka ${ }^{1} \&$ R. Brandl ${ }^{1,3}$ \\ ${ }^{1}$ Umweltforschungszentrum Leipzig-Halle GmbH, Sektion Biozönoseforschung, Theodor-Lieser Str. 4, 06120 \\ Halle/Salle, Germany; ${ }^{2}$ Molecular Ecology and Fisheries Genetics Laboratory, Department of Biological \\ Sciences, University of Hull, Hull, HU6 7RX, United Kingdom; ${ }^{3}$ Department of Animal Ecology, University of \\ Marburg, Karl-von-Frisch-Str, 35032 Marburg, Germany ( ${ }^{*}$ Correspondiong author: Phone: 0044-1482-4655804; \\ Fax: 0044-1482-465458; E-mail: b.haenfling@hull.ac.uk)
}

Received 1 November 2003; accepted 5 December 2003

Key words: allele loss, allozyme, conservation genetics, $F$-statistics, floodplains

\begin{abstract}
During the last 200 years, the riparian ecosystem along major rivers has been reduced to a few scattered remnants. Important elements of the riparian ecosystem are water bodies which were originally connected to the main river channel by annual floodings. Due to river regulations many of these remnants are now virtually isolated. In an allozyme analysis using roach, Rutilus rutilus, as a study species we demonstrate that the genetic diversity (number of alleles per locus, expected heterozygosity) of populations living within floodplain water bodies is not severely impoverished compared to the genetic diversity within the main river channel. However, we found slight differences in the allele frequencies of flood plain water bodies and the main river channel. Nevertheless, fish populations in floodplain water bodies may serve as reservoirs of autochthonous genetic material for restoration of fish populations in the main river channel after population extinction due to catastrophic accidents (e.g. industrial pollution).
\end{abstract}

\section{Introduction}

Rivers are complex ecological systems because of the diversity of aquatic habitats within the river itself and adjacent wetlands (Petts 1990; Mitsch and Gosselink 2000). These associated riparian ecosystems consist of a diverse mosaic of habitats and are considered hotspots of biodiversity (Toner and Keddy 1997; Bornette et al. 1998). Riparian ecosystems are characterised by floodplain water bodies of different size, age and isolation which are connected to the main river by seasonal floodings. Throughout the world, riparian ecosystems are under pressure from human activities (Bravard et al. 1986). In Europe riparian ecosystems have vanished completely or shrunk to a few scattered remnants along the Danube, Elbe, Rhine, Rhone and Oder (Brookes 1988; Weigers et al. 1990). Recently, programs were launched to investigate the biodiversity and ecological function of these remnants and to develop action plans for long-term conserva- tion of these endangered ecosystems (Maitland and Morgan 1997; Trockner and Schiemer 1997).

Extraordinary industrial accidents such as the Sandoz incident in the river Rhine in 1986 and the rivers Tisza and Szamos in 1999 can lead to the extinction of the autochtonous fish populations in the main river channels (Brauckmann et al. 1987; Salyi et al. 2000). After such accidents fishery authorities often release commercially important fish species (Maitland and Lyle 1990). In most cases these stocking programs use fish from allochtonous populations (Laikre and Ryman 1996), a strategy that may have many negative genetic and ecological side-effects (Hindar et al. 1991). Furthermore, efforts are rarely made to re-establish populations of less commercially important species. Hence natural or artificial flooding may facilitate the movement of individuals from floodplain water populations into the river channel, forming propagules for the regeneration of the fish fauna (Tockner and Schiemer 1997). However, before this 
possibility is accepted, two issues require clarification. First, in a natural state many floodplain water bodies were regularly connected to the main river by annual flooding, providing the opportunity for gene flow. In Europe the riparian water bodies are now more or less isolated from the river channel due to river regulations, which may lead to a decrease of genetic diversity of fish populations due to bottlenecks and genetic drift (Hänfling and Brandl 1998c). Second, this isolation may have facilitated special adaptations to the lentic environment of the floodplain water bodies and thus fish therein may be poorly adapted to river habitats.

The middle Elbe in Germany is one of the few remaining rivers in Central Europe with an extensive riparian ecosystem, even if influenced by river regulations. At present this ecosystem includes a variety of floodplain water bodies differing in size and degree of connectivity to the main river. One of the most common species in floodplain water bodies as well as in the river itself is the roach (Rutilus rutilus L., Wolter et al. 1999). The roach is an eurytopic, omnivorous and opportunistic small cyprinid with an average size of $20 \mathrm{~cm}$ (Ladiges and Vogt 1979). The aim of the present study was to investigate the genetic diversity of roach populations using polymorphisms at enzyme loci (allozymes). More specifically, we wanted to test whether (i) a significant reduction in levels of allozyme polymorphism has occurred in isolated floodplain water populations and (ii) the allelic composition of such floodplain populations is different from river populations. Multi-locus estimates of neutral genetic variation such as allozymes are rather easy to obtain and may indicate genomic diversity. They provide information about stochastic processes such as drift, genetic bottleneck effects or inbreeding which also have consequences for fitness (Carvalho et al. 2003). A recent meta-analysis showed a clear link between genetic variability estimated with neutral genetic markers and fitness estimates (Reed and Frankham 2003).

\section{Methods}

Samples of $R$. rutilus were taken from 12 sites within the main river channel of the Elbe (eastern Germany) and from 10 adjacent floodplain water bodies using electro-fishing and in a few cases fish traps (25 individuals per sample, Figure 1, Table 1). The maximum river distance between sites within the Elbe drainage was $151 \mathrm{~km}$. For comparative reasons we also included one sample each from the Rhine and Danube drainage. In total, we investigated 415 individuals from 24 populations using horizontal starch gel electrophoresis of 24 allozyme loci (Table 2). Electrophoresis followed standard protocols as described in Hillis et al. (1996).

We characterised the floodplain water bodies according to their size, age and isolation (Table 1). Size was measured from digitised maps and ranged between $0.02 \mathrm{~km}^{2}$ and $0.29 \mathrm{~km}^{2}$ which is typical for the existing remnants of riparian ecosystems in Europe (Tockner and Schiemer 1997). To determine the age of each sampled water body we consulted maps, which show the area during the years 1950, 1902 and 1852 respectively. All sampled water bodies were already shown on the map of 1902. Consequently water bodies were assigned to two categories, those present on the map of 1852 of $>150$ years and all others of 100-150 years (Table 1). According to their degree of isolation we assigned the floodplain water bodies into three categories using information on water levels and the presence or absence of a direct connection to the main river. Oxbow lakes directly connected to the main river during most of the year were scored as rank 1, water bodies not directly connected to the main river but regularly flooded as rank 2 , and water bodies isolated by flood defence dams and flooded only during exceptional high water levels as rank 3 (Table 1).

The allozyme data were analysed in the following way. GENEPOP (Raymond and Rousset 1995) was used to test for deviations of genotype frequencies from Hardy-Weinberg-equilibrium. Tests were combined across loci and across sites using Fisher's combination of probabilities. As a measure of genetic variability within samples we calculated the average number of alleles per locus $(A)$ and the mean expected heterozygosity across all loci $\left(H_{e}\right.$, Nei's unbiased estimate; Nei 1978). These two measures of genetic variability were tested for possible differences between the river channel and the floodplain water bodies as well as between floodplain water bodies of different isolation and age by ANOVA. The loss of genetic variability $\left(H_{t} / H_{0}\right)$ can be approximated as: $\left(H_{t} / H_{0}\right) \approx e^{\frac{-t}{2 N e}}$ (Frankham et al. 2002). Hence the loss increases with time (measured in number of generations $t$ ) and is greater at a small effective population size $N_{e}$. This formula was used to calculate the expected loss of genetic diversity in waterbodies for different effective population sizes $(50,100,250,500$ Individuals). All waterbodies are isolated for at least 


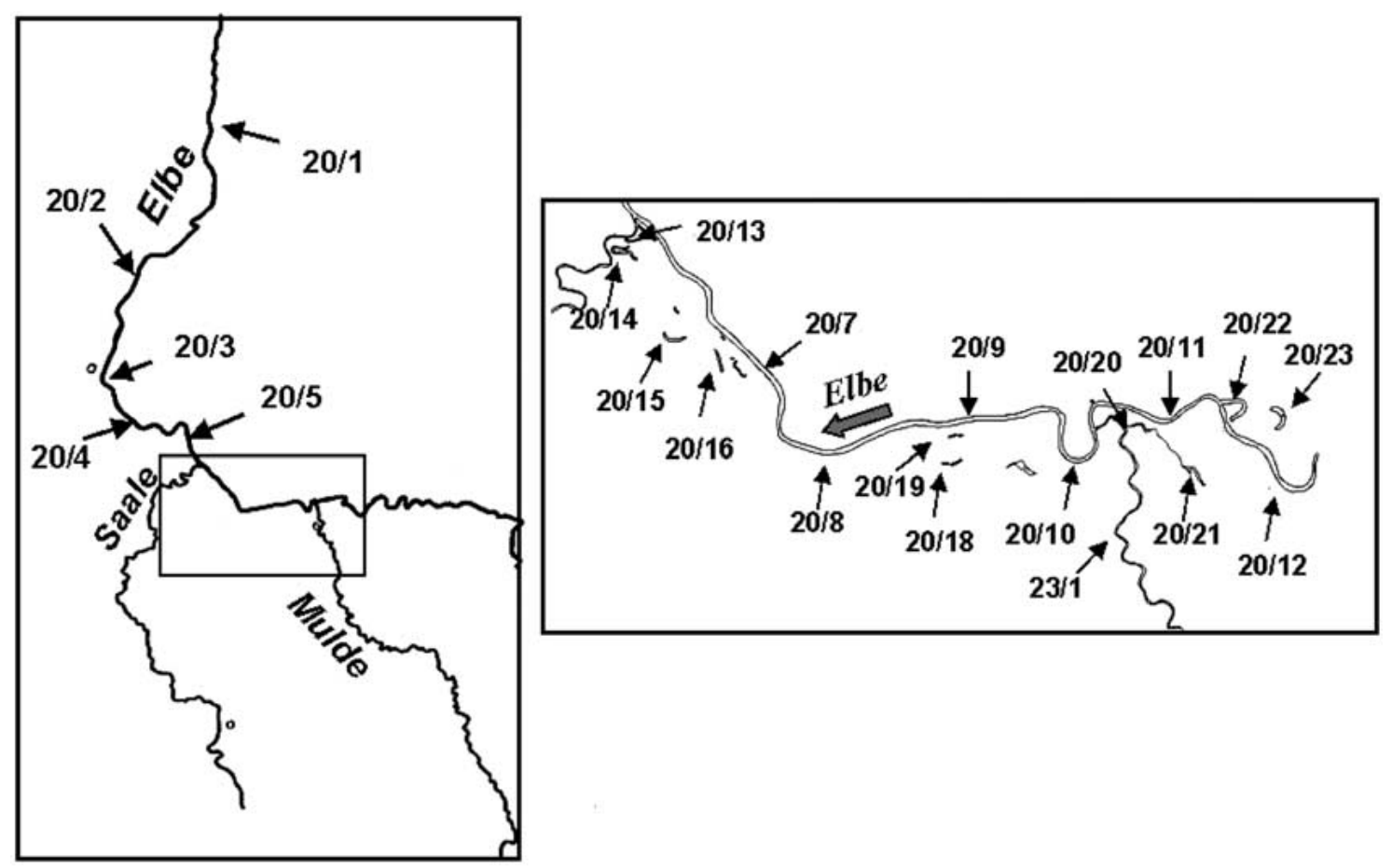

Figure 1. Sampling locations of R. rutilus in the drainage system of the river Elbe. See also Table 1.

100 years (see above). The generation time of roach is about 3 to 4 years. Hence, we calculated the expected loss of heterozygosity for up to 35 generations. Differentiation between sites was evaluated by $F_{S T}$ (Weir and Cockerham 1984), genetic distance (Nei 1978; Belkhir et al. 2000) and hierarchical AMOVA (using ARLEQUIN; Schneider et al. 2000). To visualise the genetic relationship among samples we used UPGMA cluster-analyses of genetic distances (Nei, 1978; using PHYLIP; Felsenstein 1993) and principal component analysis (PCA-GEN v. 1.2; author: Goudet; http://www.unil.ch/izea/research.html). An analysis of isolation by distance was performed for all sites from the main river. Following Slatkin (1993) we regressed $F_{S T} /\left(1-F_{S T}\right)$ on the logarithm of geographical distance between sample sites. As a measure of geographical distance between sites in the main river channel we used the distance along the river channel. For distances between floodplain water bodies we used the nearest distances of the two water bodies to the river plus the distance along the river. Reduction of gene flow between the river and the floodplain water bodies should lead to increased differentiation between river and floodplain populations. Thus, we included a dummy variable, which coded whether two water bodies are from the same type (either river or floodplain water body) or from different types. Pairwise distances are not mutually independent and therefore we used matrix permutations to test significance of partial regression coefficients (Manly 1997).

\section{Results}

Twelve of the 24 allozyme loci screened were polymorphic. Within the Elbe drainage we found 11 polymorphic loci, and across all the sampled floodplain water bodies 10 loci were polymorphic (Table 2). Nine alleles were rare with frequencies between 0.002 and 0.056 (Table 2; Elbe drainage only). Of these, only one rare allele found in the river $(A D H$, frequency: 0.002 ) was not detected in the floodplain water bodies. Distribution of alleles allowed for 107 tests for deviations from Hardy-Weinberg-equilibrium. Only one of the individual tests and none of the combined tests across loci and populations proved to be significant.

The average number of alleles per locus $(A$, including non-polymorphic loci) ranged from 1.25 to 1.42 and expected heterozygosities $\left(H_{e}\right)$ from 0.048 to 0.099 (Figure 2). When we excluded monomorphic loci, $A$ range from 1.38 to 1.77 and $H_{e}$ from 0.089 
Table 1. Sampling locations of all roach samples used in the present study. For the floodplain waters we also give area, age and isolation. $N=$ number of sampled individuals

\begin{tabular}{|c|c|c|c|c|c|c|}
\hline Code & Date & Sampling locations & $\begin{array}{l}\text { Size } \\
\left(\mathrm{km}^{2}\right)\end{array}$ & Isolation* & $\begin{array}{l}\text { Age } \\
\text { (years) }\end{array}$ & $N$ \\
\hline D12/4 & 16.12 .96 & Roter Main at Bayreuth & & & & 5 \\
\hline $\mathrm{R} 31 / 4$ & 15.07 .97 & Danube at Straubing & & & & 5 \\
\hline $20 / 1$ & 19.03 .97 & Elbe at Stendal & & & & 25 \\
\hline $20 / 2$ & 14.10 .97 & Elbe at Rogätz & & & & 25 \\
\hline $20 / 3$ & 26.04 .97 & Elbe at Magdeburg & & & & 25 \\
\hline $20 / 4$ & 14.10 .97 & Elbe at Schönbeck & & & & 25 \\
\hline $20 / 5$ & 20.10 .97 & Elbe at Barby & & & & 25 \\
\hline $20 / 7$ & 10.09 .97 & Elbe at Steckby (km 281) & & & & 25 \\
\hline $20 / 8$ & 20.08 .97 & Elbe at Aken (km 275) & & & & 24 \\
\hline $20 / 9$ & 20.08 .97 & Elbe at Brambach (km 268) & & & & 25 \\
\hline $20 / 10$ & 20.08 .97 & Elbe at Dessau (km 262) & & & & 25 \\
\hline $20 / 11$ & 21.08 .97 & Elbe east of Roßlau (km 253) & & & & 25 \\
\hline $20 / 12$ & 21.08 .97 & Elbe at Vockerode (km 245) & & & & 25 \\
\hline $23 / 1$ & 22.09 .97 & Mulde at Dessau & & & & 25 \\
\hline $20 / 13$ & 03.11 .97 & Alte Elbe Breitenhagen & 0.200 & 1 & $100-150$ & 25 \\
\hline $20 / 14$ & 03.11 .97 & Alte Saale Breitenhagen & 0.124 & 2 & $100-150$ & 25 \\
\hline $20 / 15$ & 03.11 .97 & Krügersee (Luisenhof) & 0.087 & 3 & $>150$ & 25 \\
\hline $20 / 16$ & 03.11 .97 & Goldberger See & 0.074 & 3 & $>150$ & 25 \\
\hline $20 / 18$ & 22.09 .97 & Unter and Obersee Aken & 0.039 & 2 & $>150$ & 25 \\
\hline $20 / 19$ & 22.09 .97 & Diestelsee & 0.017 & 2 & $>150$ & 25 \\
\hline $20 / 20$ & 23.09 .97 & Pelze & 0.086 & 1 & $>150$ & 25 \\
\hline $20 / 21$ & 23.09 .97 & Löbben-Leiner See & 0.164 & 3 & $>150$ & 25 \\
\hline $20 / 22$ & 29.09 .97 & Alte Elbe Matzwerder & 0.270 & 1 & $100-150$ & 25 \\
\hline $20 / 23$ & 29.09 .97 & Alte Elbe Klieken & 0.285 & 3 & $>150$ & 25 \\
\hline
\end{tabular}

*Definition of isolation: rank 1 = oxbow lakes directly connected to the main river during most of the year. $2=$ not directly connected to the main river, but regularly flooded. 3 = Isolated by flood defence dams and flooded only during exceptional high water levels.

to 0.183 . Although sample size was much lower for the Rhine and Danube, mean number of alleles was similar to the Elbe drainage and expected heterozygosity exceeded the mean value across the Elbe (Figure 2). Within the Elbe drainage, there were no differences in the average number of alleles between samples from the river channel and the floodplain water bodies (Table 3). However, we found a very small, but marginally significant, difference in the mean heterozygosity calculated across the populations of the river and floodplain water bodies (Table 3). A pairwise comparison of the heterozygosities of all river populations with those of all floodplain water populations revealed that the ratio $\left(H_{\text {floodplain }} / H_{\text {river }}\right)$ varied from 0.7 to 1.3 (mean \pm standard deviation $=0.93 \pm 0.14$; Figure 3 ). This ratio measures the relative loss of heterozygosity. We compared this ratio with the expected loss of heterozygosity for a range of effective population sizes using computer simula- tions (Frankham et al. 2002, Figure 3). Assuming a population size of 50 the expected ratio after about 35 generations was much lower than the observed ratio we obtained. For effective population sizes of 100 and more the expected ratio is within the range of those observed. We also tested for differences in the average number of alleles $(A)$ and heterozygosity $\left(H_{e}\right)$ among flood plain water bodies according to their isolation and age. None of the tests were significant (Table 3). There was no relationship between size of the water body and $A(r=0.05, P>0.3)$ or $H_{e}(r=0.03, P>$ $0.3)$.

When samples from the Rhine and Danube were included we found considerable differentiation in allozymes across populations (overall $F_{S T}=0.036$ ). A permutation test across individuals showed that this differentiation was highly significant (all 999 values from permutations were smaller than the original value). However, a hierarchical AMOVA revealed that 
Table 2. Enzyme systems used to investigate genetic variation in Rutilus populations. $A_{\text {total }}$ gives the number of alleles detected for each locus across all populations, including Rhine and Danube; $A_{E l b e}$ for all sites from the main river channel of the Elbe and $A_{\text {flood }}$ for floodplain waterbodies. The last column gives the average frequency of the rarest allele

\begin{tabular}{|c|c|c|c|c|c|c|c|}
\hline Enzyme system & EC no. & Locus $^{\mathrm{a}}$ & $\begin{array}{l}\text { Buffer } \\
\text { system }^{b}\end{array}$ & $A_{\text {total }}$ & $A_{\text {Elbe }}$ & $A_{\text {flood }}$ & $\begin{array}{l}\text { Rarest } \\
\text { allele }\end{array}$ \\
\hline Aspartate aminotransferase & 2.6.1.1 & AAT- $1 *$ & $\mathrm{~S} 4$ & 2 & 2 & 2 & 0.265 \\
\hline Alcohol dehydrogenase & 1.1.1.1 & $A D H^{*}$ & EBT & 2 & 2 & 1 & 0.002 \\
\hline Creatine kinase & 2.7.3.2. & $C K-1^{*}$ & EBT & 1 & 1 & 1 & \\
\hline \multirow[t]{3}{*}{ Esterase } & 3.1.1.x & EST-3* & $\mathrm{S} 1$ & 2 & 2 & 2 & 0.168 \\
\hline & & EST-4* & $\mathrm{S} 1$ & 1 & 1 & 1 & \\
\hline & & EST-5* & $\mathrm{S} 1$ & 1 & 1 & 1 & \\
\hline \multirow[t]{2}{*}{ Fumarate hydratase } & 4.2.1.2 & $F H-1^{*}$ & EBT & 1 & 1 & 1 & \\
\hline & & $F H-2^{*}$ & EBT & 1 & 1 & 1 & \\
\hline Glucose-3-phosphate dehydrogenase & 1.1.1.8 & $G 3 P D H^{*}$ & TCE & 2 & 2 & 2 & 0.010 \\
\hline Glucose-6-phosphate dehydrogenase & 1.1.1.49 & $G 6 P D H^{*}$ & EBT & 1 & 1 & 1 & \\
\hline \multirow[t]{3}{*}{ General protein } & & $G P-1$ & EBT & 1 & 1 & 1 & \\
\hline & & $G P-2$ & EBT & 1 & 1 & 1 & \\
\hline & & $G P-4$ & EBT & 1 & 1 & 1 & \\
\hline \multirow[t]{2}{*}{ Glucose-6-phosphate isomerase } & 5.3.1.9 & $G P I-1^{*}$ & $\mathrm{~S} 1$ & 2 & 1 & 1 & \\
\hline & & $G P I-2^{*}$ & $\mathrm{~S} 1$ & 2 & 2 & 2 & 0.030 \\
\hline L-Iditol dehydrogenase & 1.1.1.14 & $I D D H^{*}$ & TCE & 3 & 2 & 2 & 0.006 \\
\hline Isocitrate dehydrogenase & 1.1.1.42 & $I D H P-1^{*}$ & TCE & 2 & 2 & 2 & 0.002 \\
\hline Lactate dehydrogenase & 1.1.1.27 & $L D H^{*}$ & TCE & 1 & 1 & 1 & \\
\hline \multirow[t]{2}{*}{ Malate dehydrogenase } & 1.1.1.37 & $M D H-1^{*}$ & EBT & 2 & 1 & 1 & \\
\hline & & $M D H-2^{*}$ & EBT & 1 & 1 & 1 & \\
\hline Mannose-6-phosphate isomerase & 5.3.1.8 & $M P I^{*}$ & $\mathrm{~S} 4$ & 2 & 2 & 2 & 0.003 \\
\hline 6-Phosphogluconate dehydrogenase & 1.1.1.44 & $P G D H^{*}$ & TCE & 4 & 4 & 4 & 0.016 \\
\hline Phosphoglucomutase & 5.4 .2 .2 & $P G M^{*}$ & S4 & 2 & 2 & 2 & 0.056 \\
\hline Superoxide dismutase & 1.15.1.1 & $S O D^{*}$ & EBT & 2 & 2 & 2 & 0.046 \\
\hline
\end{tabular}

${ }^{\mathrm{a}} \mathrm{S} 1$ : Tris-hydrochloric acid. Electrode $\mathrm{pH}$ 8.2/ gel 8.5. S4: Tris-citrate. Electrode $\mathrm{pH}$ 6.0/ gel pH 6.3. EBT: Tris-borate EDTA. Electrode/gel pH 8.6. TCE: Tris-citrate-EDTA. Electrode/gel pH 7.0. Buffer recipes were modified from (Selander et al. 1971); S1 and S4) or from Hillis et al. (1996; EBT and TCE). All staining procedures were performed according to Hillis et al. (1996). ${ }^{\mathrm{b}}$ Enzyme nomenclature and locus designation follow (Shaklee et al. 1990).

the majority of these differences among populations were among, rather than within drainages (Table 4). Analysing the Elbe populations separately only $1.8 \%$ $\left(F_{S T}=0.018\right)$ of the variation was found among populations. The pair-wise $F_{S T}$ values ranged from slightly negative values up to 0.15 . Only 61 out of 231 possible values were significant at a $5 \%$ level (GENETIX; Belkhir et al. 2000; 999 permutations of individuals across populations).

Average Nei-distance was highest between the Rhine and Elbe populations (mean \pm standard deviation; $0.043 \pm 0.004)$ and between Danube and Elbe populations $(0.021 \pm 0.005)$. The distance between the sample from the Rhine and the sample from the Danube was considerably lower (0.003). UPGMA cluster-analysis visualised the large differences among drainages quite clearly but showed no convincing geographic structure within the Elbe drainage (Figure 4a). Hierarchical clustering may not be appropriate to analyse the genetic relationship between geographic samples, thus we also used principal component analyses (Figure 4b). The first three axes explained $85 \%$ of the total variation (axis $1-48 \%$, axis $2-$ $29 \%$, axis $3-10 \%$ ). We performed three ANOVAs testing for differences in the mean scores between samples from the main river and the floodplain water bodies. Along the first and third axes the scores differed significantly (Figure 4b; Table 3). Analysing the scores along the three principal components for the floodplain water bodies, we found a significant difference between the three categories of isolation along the second principal component (Table 3). This suggests that the degree of isolation influences genetic differentiation. After a Bonferroni correc- 

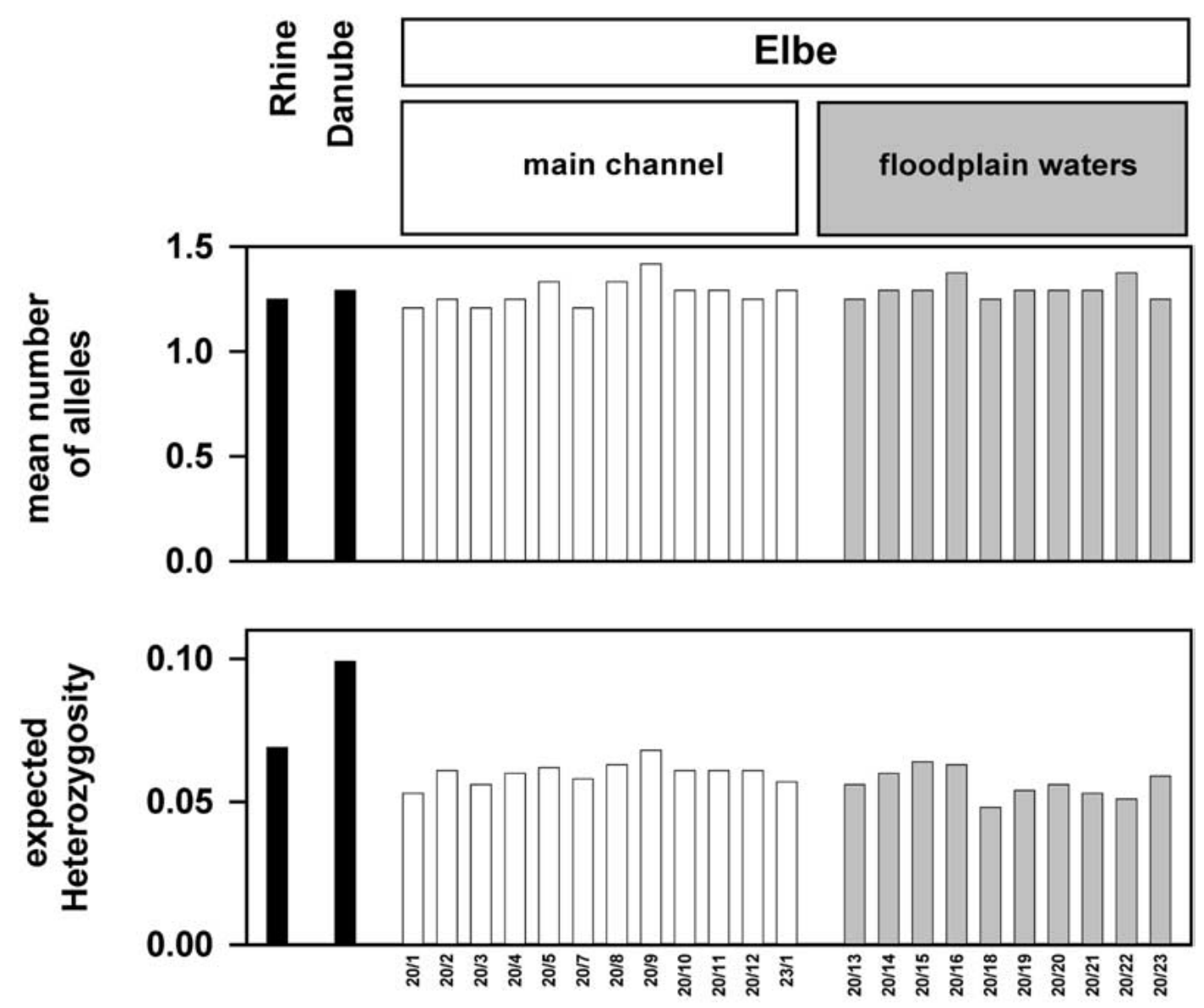

Figure 2. Genetic variability within the 24 samples of $R$. rutilus. Two measures of genetic variability (mean number of alleles, $A$, and expected heterozygosity, $H_{e}$ ) were calculated using all data including the monomorphic loci. Samples are coded according to Table 1.

Table 3. Differences in means of genetic variability $\left(A, H_{e}\right)$ and genetic differentiation (PC1 to PC3; see Figure 4b) between populations sampled in the main river channel and floodplain water bodies. For all the floodplain water bodies we also give the mean for the three isolation levels and the age of the water bodies (for definitions see material and methods and Table 1)

\begin{tabular}{|c|c|c|c|c|c|}
\hline & $A$ & $H_{e}$ & PC1 & $\mathrm{PC} 2$ & PC3 \\
\hline River & $1.28 \pm 0.062$ & $0.060 \pm 0.0039$ & $0.065 \pm 0.171$ & $0.030 \pm 0.097$ & $\mathbf{0 . 0 3 2} \pm \mathbf{0 . 0 7 1}$ \\
\hline Floodplain & $1.32 \pm 0.046$ & $0.056 \pm 0.0052$ & $-\mathbf{0 . 0 7 7} \pm \mathbf{0 . 1 1 1}$ & $-0.036 \pm 0.147$ & $-\mathbf{0 . 0 3 6} \pm \mathbf{0 . 0 5 7}$ \\
\hline$F_{1,20}(P)^{*}$ & $0.6(>0.3)$ & $3.4(0.08)$ & $5.1(0.04)$ & $1.6(0.22)$ & $5.7(0.03)$ \\
\hline \multicolumn{6}{|c|}{ Ffloodplain water bodies only: } \\
\hline Isolation 1 & $1.30 \pm 0.064$ & $0.054 \pm 0.0029$ & $-0.066 \pm 0.141$ & $-0.159 \pm 0.009$ & $-0.025 \pm 0.025$ \\
\hline Isolation 2 & $1.28 \pm 0.024$ & $0.054 \pm 0.0060$ & $-0.084 \pm 0.088$ & $-0.090 \pm 0.069$ & $-0.020 \pm 0.092$ \\
\hline Isolation 3 & $1.30 \pm 0.052$ & $0.060 \pm 0.0050$ & $-0.080 \pm 0.086$ & $\mathbf{0 . 0 9 7} \pm \mathbf{0 . 1 4 2}$ & $-0.057 \pm 0.051$ \\
\hline$F_{2,7}(P)^{*}$ & $0.28(>0.3)$ & $1.77(0.24)$ & $0.02(>0.3)$ & $6.2(0.03)$ & $0.39(>0.3)$ \\
\hline \multicolumn{6}{|c|}{ Floodplain water bodies only: } \\
\hline Young & $1.31 \pm 0.063$ & $0.056 \pm 0.0046$ & $-0.169 \pm 0.075$ & $-0.115 \pm 0.085$ & $-0.000 \pm 0.062$ \\
\hline Old & $1.29 \pm 0.042$ & $0.057 \pm 0.0058$ & $-0.037 \pm 0.103$ & $-0.002 \pm 0.160$ & $-0.052 \pm 0.051$ \\
\hline$F_{1,8}(P)^{*}$ & $0.17(>0.3)$ & $0.08(>0.3)$ & $3.8(0.09)$ & $1.3(0.29)$ & $1.9(0.20)$ \\
\hline
\end{tabular}

${ }^{*}$ Differences in means between categories were tested using an ANOVA. Results, which are significant on a 5\% level, are in bold. 


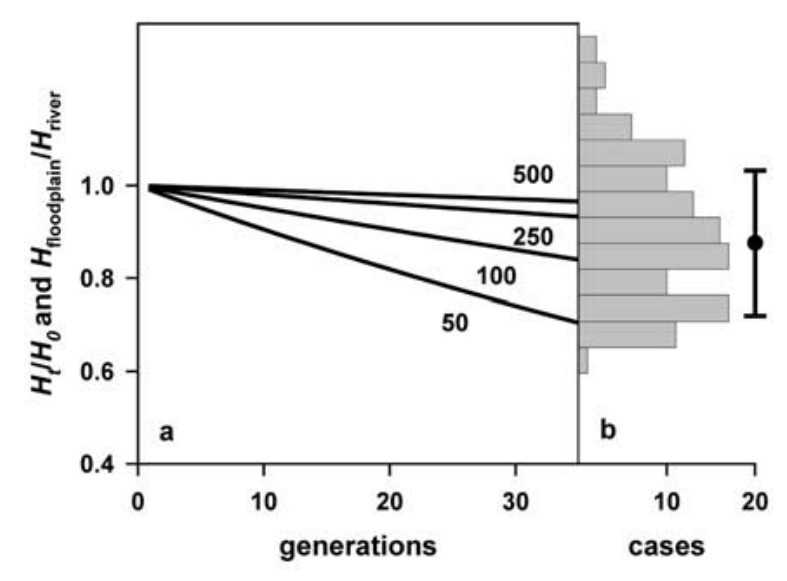

Figure 3. (a) Expected loss of heterozygosity (as a proportion of initial heterozygosity, $H_{t} / H_{0}$ ) with an increasing number of generations for scenarios with effective population sizes between 50 to 500. (b) Detected change in heterozygosity. Histogram of all possible ratios of heterozygosity between floodplain water bodies and samples from the main river $\left(H_{\text {floodplain }} / H_{\text {river }}\right)$ as well as the mean and the standard deviation. Note that the expected loss after 30 to 35 generations and $\mathrm{Ne}$ of 50 is much lower than the mean. Hence our data should have had sufficient power to detect severe bottlenecks for populations within the floodplain water bodies.

tion for multiple testing, however, these differences remained only marginally significant $(P<0.1)$.

A matrix correlation between $F_{S T} /\left(1-F_{S T}\right)$ and geographic distance and the dummy variable coding for the type of comparison revealed no correlation between geographic distance and genetic differentiation $(P=0.07 ; 999$ randomisations; after fitting the dummy variable). The regression coefficient even had a positive sign, which is contrary to expectation. However, we found a clear influence of the dummy variable $(P=0.01$; after fitting distance), with a positive regression coefficient indicating that floodplain water populations are genetically different from the main river population Separate matrix plots for the main river as well as the floodplain water bodies (not shown) also provided no indication of a correlation of genetic differentiation with distance. The scatter was rather similar (mean $F_{S T} \pm$ standard deviation: main river $0.014 \pm 0.026$; floodplain waterbodies $0.015 \pm$ 0.019 .

\section{Discussion}

From our analyses three main results appear. First, there is considerable genetic differentiation among drainages. Second, the degree of differentiation in allozymes between populations in the main river
Table 4. Results of the AMOVA using drainages as a hierarchical level

\begin{tabular}{lcll}
\hline $\begin{array}{l}\text { Source of } \\
\text { variation }\end{array}$ & d.f. & $\begin{array}{l}\text { Variance } \\
\text { components* }\end{array}$ & $\begin{array}{l}\text { Percentage } \\
\text { of variation }\end{array}$ \\
\hline $\begin{array}{l}\text { Among drainages } \\
\text { Among populations } \\
\text { within drainages }\end{array}$ & 21 & 0.36 & 33.12 \\
Within populations & 1094 & 0.70 & 1.18 \\
Total & 1117 & 1.07 & 65.71 \\
\hline
\end{tabular}

*Judged from 999 permutations, all variance components are highly significant $(P=0.01)$.

channel and the floodplain water bodies is low, but nevertheless significant. Third, we found little difference in the level of genetic variability between populations sampled in the main river channel and in the floodplain water bodies.

\section{Marked genetic differentiation among drainages}

The level of differentiation among drainages is of a similar order of magnitude to that found for other opportunistic, mobile and common cyprinids such as Leuciscus cephalus across the same three drainages (Hänfling and Brandl 1998a). For fish species it is well known that historical processes influence genetic structure across drainages (Carvalho 1993). Thus, the difference between populations living in the Rhine and Danube versus the Elbe may reflect the biogeographic history. The Danube is considered as one of the main refuges of fish populations during the Pleistocene (Banarescu 1991). The higher level of heterozygosity in the Danube populations is consistent with this view, although our sample size is too small for any firm conclusions.

\section{Low levels of differentiation within drainages}

Compared to other freshwater fish (Ward et al. 1994; Hänfling and Brandl 1998b) the differentiation among roach populations within the Elbe drainage $\left(F_{S T}=\right.$ 0.02 ) is low. This is consistent with previous studies on this species (Bouvet et al. 1995; Wolter 1999). Although the roach is a mobile species with a wide range habitat between 75 and 3820 meters within a river and long-distance migrations of up to $10 \mathrm{~km}$ (Baade and Fredrich 1998) it was still unexpected to find spatial genetic structure to be that low.

Although quite small, we found some indication for genetic differentiation between river and flood- 
a

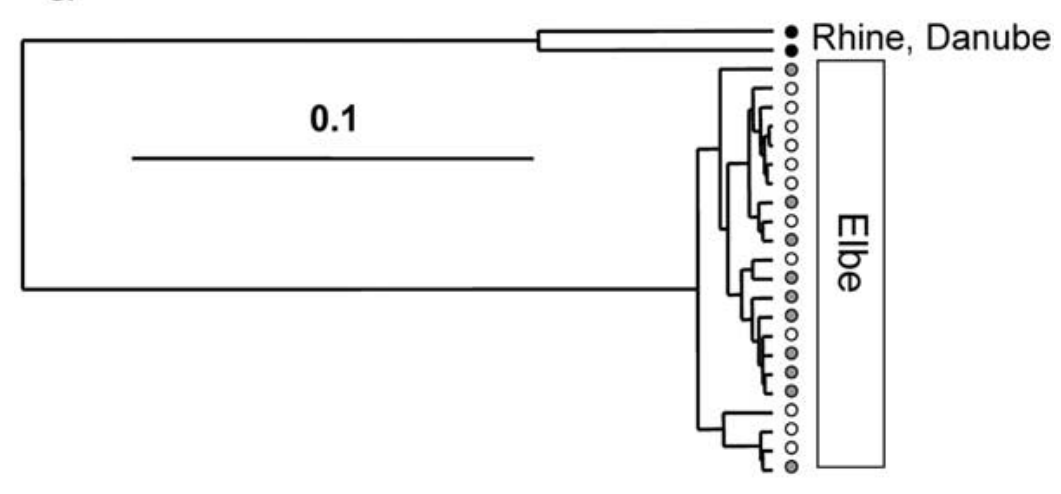

b

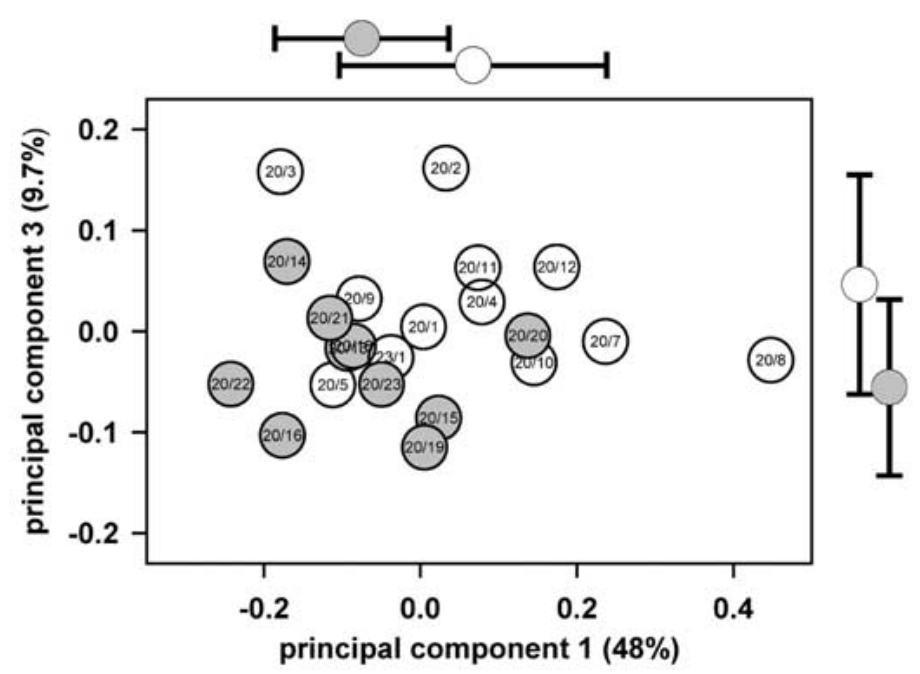

Figure 4. Geographic patterns of genetic differentiation between roach populations (a) UPGMA tree of unbiased Nei-distances among populations of the Elbe as well as samples from the Danube and Rhine drainage (Nei-distance based on allele frequencies of all allozyme loci). (b) Ordination of sampling locations along the first and third principal component of populations from the Elbe drainage based on distribution of genotypes from 10 polymorphic allozyme loci. In (a) and (b) grey symbols mark samples from floodplain water bodies, white symbols samples from the main river channel (for statistical tests see Table 3).

plain habitats. All our tests showed the same trend: independent of geographical distance, populations from floodplain water bodies were genetically closer to each other than to samples from the main river. It remains to be seen if these alloyzme polymorphisms are neutral (Hillis et al. 1996), as there is evidence for the adaptive value of certain alleles (Mitton and Koehn 1975; Place and Powers 1979; Gillespie and Guttmann 1989; Heithaus and Laushman 1997), and it is possible that our findings are indicative of adaptive differences among allozyme genotypes to lentic or lotic habitats, respectively. However, further experimental work is needed to test this possibility.

\section{High levels of genetic variability within populations}

Compared to other fish species, the roach populations we sampled showed a fairly high level of average heterozygosity. The value of 0.06 found during our study is above the average for fresh water fish of 0.046 (Ward et al. 1994). Other studies of roach populations report similar or even higher levels (Wolter 1999; Bouvet et al. 1991). Widespread and common animals often show higher levels of heterozygosity than animals with restricted distribution (Frankham 1996; Hänfling and Brandl 1998a). It is therefore not surprising that the genetic variation in a widespread and common animal such as roach is high 
in the main river channel (Frankham 1996; Hänfling and Brandl 1998a). Nevertheless, the genetic variability is also high in small and isolated floodplain waters. Theory predicts a decrease of genetic variability with a positive correlation between genetic variability and effective population size (Frankham 2002). In a previous study we found such a correlation for natural populations of Cottus gobio (Hänfling and Brandl 1998c). However, neither habitat size nor degree of isolation of roach populations had an impact on genetic variability. Furthermore the comparison between the expected decrease in heterozygosity in an isolated population after 100 years $(\approx 30$ generations) and the decrease inferred from our samples suggests that floodplain populations must have maintained average effective population sizes over 100 (note that Figure 3 shows that our data should have been sufficient to detect severe bottlenecks). This is further supported by the fact that nine out of ten rare alleles present in the main river population were also found in the populations of the floodplain water bodies. Rare alleles are more sensitive to genetic drift than heterozygosity. For example simulations using re-sampling techniques (data not shown) indicate that an allele with an initial frequency of 0.01 has an $86 \%$ chance to be lost after 35 generations at a population size of 100. This fact can also be used to infer bottlenecks from population genetic data (for details see Cornuet and Luikart 1996), and using the program BOTTLENECK we did not detect a significant excess of heterozygosity in any population (Cornuet and Luikart 1996). There are at least two processes that may explain high genetic variation within populations and low differentiation between populations. Firstly, as noted above, population sizes within small floodplain water bodies are sufficiently large to counter the action of genetic drift. Secondly, high levels of gene flow are maintained by rare flooding events and in some cases by small ditches which connect floodplain waters with the main river.

\section{Implication for conservation}

Despite the increasing awareness about the importance of quantitative genetics in conservation, neutral markers remain an important approach (Carvalho et al. 2003). Although genetic variation estimated from neutral markers is not always well correlated with quantitative variation (Reed and Frankham 2001) both approaches can provide independently valuable information about fitness. In the absence of direct and often unobtainable estimates of fitness, variation at neutral loci provide a valuable proxy (Reed and Frankham 2003). The analyses of genetic variability within, and differentiation among, populations showed that roach populations from floodplain water bodies are genetically similar to populations from the main river channel. We cannot exclude the possibility that populations have developed local adaptation to lotic and lentic habitats respectively. Nevertheless, the fragmentation and isolation of these water bodies during the last 200 years had little influence on genetic variability. The large population sizes of roach as well as rare flooding events have buffered the populations within the floodplain water bodies against the loss of variation. Thus, in the case of a catastrophic event causing the local extinction of fish populations in the main river, the floodplain water bodies may form a reservoir for re-colonisation. As the populations within the floodplain water bodies showed similar genetic variability and had the same alleles, floodplain waterbodies provide a chance to restore the genetic diversity of fish populations in the main river, at least for the roach and probably also other abundant fish species. Note that we found considerable differentiation between drainages indicating that these populations have evolved in allopatric isolation and represent independent evolutionary significant units (ESUs). In contrast our results show that populations from the same drainage have a longer shared evolutionary history and possible contemporary gene flow. The importance of maintaining high levels of within species diversity is now widely excepted and consequently it has become an important goal in conservation programmes to protect ESUs (Ryman et al. 1995; Vrijenhoek 1998; Frankham et al. 2002). It is therefore likely that the floodplain population will provide the primary source for any reintroduction project following a severe pollution event.

\section{Acknowledgements}

We are grateful to the following people, who helped during the sampling process: R. Klupp, K. Hempel, L. Mayer, H. Menke K. Pinkert, U. Raschewski and all fishery owners who kindly gave their permission. R. Trigg and and D. Weetman worked through several drafts of the manuscript. C. van Oosterhout for making a computer programme available to simulate the loss of rare alleles. The subject editor and three anonymous referees provided helpful suggestions. 


\section{References}

Baade U, Fredrich F (1998) Movement and pattern of activity of the roach in the River Spree, Germany. J. Fish Biol., 52, 1165-1174.

Banarescu P (1991) Zoogeography of fresh waters. Vol. 2. Distribution and Dispersal of Freshwater Animals in North America and Eurasia. Aula Verlag, Wiesbaden.

Belkhir K, Borsa P, Goudet J, Chikli L, Bonhomme F (2000) GENETIX, logiciel sous WindowsTM pour la génétique des populations, version 4.01. University of Montpellier II, Montpellier.

Bernatchez L, Chouinard A, Lu GQ (1999) Integrating molecular genetics and ecology in studies of adaptive radiation: Whitefish, Coregonus sp., as a case study. 68, 173-194.

Bornette G, Amoros C, Lamouroux N (1998) Aquatic plant diversity in riverine wetlands: The role of connectivity. Freshwater Biol., 39, 267-283.

Bouvet Y, Bobin M, Maslin JL, Pattee E (1995) The genetic structure of roach populations in two contrasted large rivers. Hydrobiologia, 303, 229-234.

Bouvet Y, Soewardi K, Pattee E (1991) The discrimination of roach Rutilus rutilus (Linnaeus, 1758) populations in different parts of a river system. An investigation using biochemical markers. Hydrobiologia, 209, 161-167.

Brauckmann U, Jöchle G, Pinter I, Schmitz W, Vobis H (1987) Der ökologische Zustand des Rheins nach dem Sandoz-Unfall. Landesamt für Umweltschutz, Institut fur Wasser und Abfallwirtschaft, Bonn.

Bravard JP, Amoros C, Pautou C (1986) Impact of civil engineering works on the successions of communities in a fluvial system: A methodological and predictive approach applied to a section of the Upper Rhone. Oikos, 47, 92-111.

Brookes A (1988) Channelised Rivers: Perspectives for Environmental Management. John Wiley \& Sons, Inc., Chichester.

Carvalho G (1993) Evolutionary aspects of fish distribution: Genetic variability and adaptation. J. Fish Biol., 43, 53-73.

Carvalho GR, van Oosterhout C, Hauser L, Magurran AE (2003) Measuring genetic variation in wild populations: From molecular markers to adaptive traits. In: Genes in the Environment (eds. Hails AS, Beringer JE, Godfray HCJ). Blackwell Science Ltd, Oxford, UK.

Cornuet JM, Luikart G (1996) Description and power analysis of two tests for detecting recent population bottlenecks from allele frequency data. Genetics, 144, 2001-2014.

Felsenstein J (1993) PHYLIP (Phylogeny Inference Package), version $3.5 c$. Department of Genetics, University of Washington, Seattle.

Frankham R (1996) Relationship of genetic variation to population size in wildlife. Cons. Biol., 10, 1500-1508.

Frankham R, Ballou JD, Briscoe DA (2002) Introduction to Conservation Genetics. Cambridge University Press, Cambridge.

Gillespie RB, Guttmann SI (1989) Effects of contaminants on the frequency of allozymes in populations of the central stoneroller. Environ. Toxicol. Chem., 8, 309-317.

Hänfling B, Brandl R (1998a) Genetic and morphological variation in a common European cyprinid, Leuciscus cephalus within and across central European drainages. J. Fish Biol., 52, 706-715.

Hänfling B, Brandl R (1998b) Genetic differentiation of the bullhead Cottus gobio L. across watersheds in central Europe: Evidence for two taxa. Heredity, 80, 110-117.

Hänfling B, Brandl R (1998c) Genetic variability, population size and isolation of distinct populations in the freshwater fish Cottus gobio L. Mol. Ecol., 7, 1625-1632.
Heithaus MR, Laushman RH (1997) Genetic variation and conservation of stream fishes: Influence of ecology, life history and water quality. Can. J. Fish. Aqu. Sci., 54, 1822-1836.

Hillis DM, Moritz C, Mable BK (1996) Molecular Systematics. Sinauer Associates, Inc., Sunderland, MA, p. 655.

Hindar K, Ryman N, Utter F (1991) Genetic effects of cultured fish on natural fish populations. Can. J. Fish. Aquat. Sci., 48, 945957.

Ladiges W, Vogt D (1979) Die Süßwasserfische Europas. Bis zum Ural und Kaspischen Meer. Paul Parey Verlag, Hamburg.

Laikre L, Ryman N (1996) Effects on intraspecific biodiversity from harvesting and enhancing natural populations. Ambio, 25, 504509.

Maitland PS, Lyle AA (1990) Practical conservation of British fishes: Current action on six declining species. J. Fish. Biol., 37A, 255-256.

Maitland PS, Morgan NC (1997) Conservation Management of Freshwater Habitats. Lakes, Rivers and Wetlands. Chapman \& Hall, London.

Manly BFJ (1997) RT, a Program for Randomization Testing, version 2.1. West-Inc., Cheyenne/Wyoming.

Mitsch WJ, Gosselink JG (2000) Wetlands, 3rd edn. John Wiley \& Sons, Inc., New York.

Mitton JB, Koehn RK (1975) Genetic organisation and adaptive response of allozymes to ecological variables in Fundulus heteroclitus. Genetics, 79, 97-111.

Nei M (1978) Estimation of average heterozygosity and genetic distance from a small number of individuals. Genetics, 89, 583-590.

Petts GE (1990) Forested river corridors: A lost resource. In: Water, Engineering and Landscape (eds. Cosgrove D, Petts GE), pp. 12-34. Belhaven Press, London.

Place AR, Powers DA (1979) Genetic variation and relative catalytic efficiencies: Lactate dehydrogenase B allozymes of Fundulus heteroclitus. Proc. Nat. Acad. Sci. U.S.A., 76, 2354 2358.

Raymond M, Rousset F (1995) GENEPOP (version 1.2): A population genetic software for exact tests and ecumenicism. J. Hered., 86, 248-249.

Reed DH, Frankham R (2001) How closely correlated are molecular and quantitative measures of genetic variation? A meta-analysis. Evolution, 55, 1095-1103.

Reed DH, Frankham R (2003) Correlation between fitness and genetic diversity. Conserv. Biol., 17, 230-237.

Ryman N, Utter F, Laikre L (1995) Protection of intraspecific biodiversity of exploited fishes. Rev. Fish. Biol. Fisher., 5, 417-446.

Salyi G, Csaba G, Darin EG, Orosz E, Lang M, Majoros G, Kunsagi Z, Niklesz C (2000) Effect of thr cyanide and heavy metal pollution passed in the river Szamos and Tisza on the aquatic flora and fauna with special regard to the fish. Magyar Allatrvosok Lapja, 122, 493-497.

Schneider S, Kueffer JM, Roessli D, Excoffier L (2000) Arlequin, a Software for Population Genetic Data Analysis, version 2.0. University of Geneva, Geneva.

Selander RK, Smith MH, Young SY, Johnson WE, Gentry JB (1971) Biochemical polymorphism and systematics in the genus Peromyscus. Univ. Texas Pub., 7103, 49-90.

Shaklee LB, Allendorf FW, Morizot DC, Whitt GS (1990) Gene nomenclature for protein-coding loci in fish. T. Am. Fish. Soc., 119, 2-15.

Slatkin M (1993) Isolation by distance in equilibrium and nonequilibrium populations. Evolution, 39, 53-65. 
Toner M, Keddy P (1997) River hydrology and riparian wetlands: A predictive model for ecological assembly. Ecol. Appl., 7, 236246.

Trockner K, Schiemer F (1997) Ecological aspects of the restoration strategy for a river-floodplain system on the river Danube in Austria. Global Ecol. Biogeogr., 6, 321-329.

Vrijenhoek RC (1998) Conservation genetics of freshwater fish. $J$. Fish. Biol., 53, 394-412.

Ward RD, Woodwark M, Skibinski DOF (1994) A comparison of genetic diversity levels in marine, freshwater and anadromous fish. J. Fish. Biol., 44, 213-232.

Weigers EL, Zinke A, Gurtzweiler K (1990) Present situation of the European floodplain forests. Forest Ecol. Manag., 33/34, 5-12.
Weir BS, Cockerham CC (1984) Estimating $F$-statistics for the analysis of population structure. Evolution, 38, 1358-1370.

Wolter C (1999) Comparison of intraspecific variability in four common cyprinids, Abramis brama, Abramis bjoerkna, Rutilus rutilus and Scardinius erythrophthalmus, within and between lowland river systems. Hydrobiologia, 394, 163-177.

Wolter C, Bischoff A, Tautenhahn M, Vilcinkas A (1999) The fish assemblage of the Lower Oder Valley: Species composition, abundances, stock development and fish ecological importance of the polder areas. In: Das Untere Odertal. Auswirkung der periodischen Überschwemmungen auf Biozönosen und Arten (eds. Dohle W, Bornkamm R, Weigmann G). Schweizerbart'sche Verlagsbuchhandlung, Stuttgart. 
